NEVADA BUREAU OF MINES AND GEOLOGY

REPORT 21

\title{
GEOTHERMAL EXPLORATION AND DEVELOPMENT IN NEVADA THROUGH 1973
}

BY LARRY J. GARSIDE

A brief description of Nevada's geothermal resources, and exploration activity for geothermal power through 1973. The use, geology, exploration, and regulation of the State's geothermal energy resources are discussed.

MACKAY SCHOOL OF MINES 


\section{DISCLAIMER}

This report was prepared as an account of work sponsored by an agency of the United States Government. Neither the United States Government nor any agency Thereof, nor any of their employees, makes any warranty, express or implied, or assumes any legal liability or responsibility for the accuracy, completeness, or usefulness of any information, apparatus, product, or process disclosed, or represents that its use would not infringe privately owned rights. Reference herein to any specific commercial product, process, or service by trade name, trademark, manufacturer, or otherwise does not necessarily constitute or imply its endorsement, recommendation, or favoring by the United States Government or any agency thereof. The views and opinions of authors expressed herein do not necessarily state or reflect those of the United States Government or any agency thereof. 


\section{DISCLAIMER}

Portions of this document may be illegible in electronic image products. Images are produced from the best available original document. 


\section{NEVADA BUREAU OF MINES AND GEOLOGY NEVADA MINING ANALYTICAL LABORATORY}

John H. Schilling, Director

* Salin Akhtar, Metallurgist

Merrill Allen, Chemist and Metallurgist

Patrick L Beaulieu, Chemist

Edward C. Bingler, Environmental Geologist

Ed Bittleston, Geophysics Technician

Harold F. Bonham, Jr., Geologist

Frank W. Bowdish, Extractive Metallurgist

* Marcel Deguire, Student Assistant

John F. Edwards, Laboratory Technician

- John W. Erwin, Geophysicist

* Edward D. Gardner, Laboratory Mechanic

Larry J. Garside, Geologist

* James L. Hendrix, Chemical Engineer

-William Hill, Student Assistant

- Liang-chi Hsu, Mineralogist and Geochemist

*Robert Kirkham, Student Assistant
Arlene Kramer, Secretary

* Jean Lowe, Accountant

Ira A. Lutsey, Jr., Technical Editor

Kenneth V. Luza, Engineering Geologist

Coy Miller, Electronics Technician

Helen Mossman, Office Manager

* J. B. Murphy, Mineral Preparator

Susan Nichols, Technical Illustrator

*Ruth Nolte, Student Assistant

Keith G. Papke, Industrial Minerals Geologist

- Albert Roberts, Mining Engineer

LaVerne B. Rollin, Public Relations and Editing

* Alan S. Ryall, Jr., Seismologist

Louis Scalise, Assistant Mineral Preparator

* Lynn Titus, Student Assistant

Georgianna Trexler, Secretary

Part Time 


\section{NEVADA BUREAU OF MINES AND GEOLOGY}

REPORT 21

\section{GEOTHERMAL EXPLORATION \\ AND DEVELOPMENT IN NEVADA \\ THROUGH 1973}

BY LARRY J. GARSIDE

A brief description of Nevada's geothermal resources, and exploration activity for geothermal power through 1973 . The use, geology, exploration, and regulation of the State's geothermal energy resources are discussed.

MACKAY SCHOOL OF MINES

UNIVERSITY OF NEVADA - RENO

1974 


\title{
UNIVERSITY OF NEVADA SYSTEM
}

\author{
Board of Regents
}

Harold J. Jacobsen, Chaiman

Fred M. Anderson, M.D.

Louis E. Lombardi, M.D.

James Buchanan

Nedra Joyce

William W. Morris

Rev. Joseph Kohn

Melvin Steninger

Helen R. Thompson

Neil D. Humphrey, Chancellor

\section{UNIVERSITY OF NEVADA, RENO}

James T. Anderson, Acting President

\section{MACKAY SCHOOL OF MINES}

Arthur Baker, III, Dean

First edition, furst printing, $1974: 1,500$ copies

Composed in IBM Press Roman type at the Nevada Bureau of Mines and Geology

Printed by Central Office Services, Univ. of Nevada, Reno

Editor: Ira A. Lutsey

Composition: Georgianna Trexler

Cartography: Susan L. Nichols

For sale by the Nevada Bureau of Mines and Geology, University of Nevada, Reno, Nevada, 89507. Price \$1.00. 


\section{CONTENTS}

PAGE

General $\ldots \ldots \ldots \ldots \ldots \ldots \ldots \ldots \ldots \ldots \ldots \ldots \ldots \ldots \ldots \ldots$

Nevada Resources $\ldots \ldots \ldots \ldots, \ldots \ldots \ldots \ldots \ldots \ldots \ldots \ldots \ldots \ldots \ldots \ldots 1$

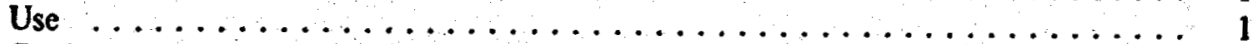

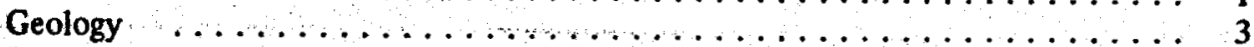

Exploration $\ldots \ldots \ldots \ldots \ldots \ldots \ldots \ldots \ldots \ldots \ldots \ldots \ldots \ldots \ldots \ldots$

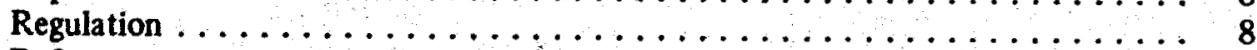

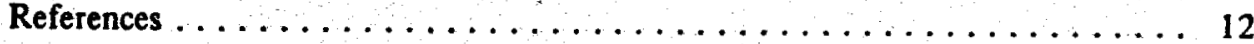

\section{ILLUSTRATIONS}

Figure 1. Hot springs and geothermal wells in Nevada $\ldots \ldots \ldots \ldots \ldots \ldots 2$

2. Variation of the boiling point of water with altitude above sea level

3. Variation of the boiling point of water with depth below a water surface at sea level $\ldots \ldots \ldots \ldots \ldots \ldots \ldots \ldots, 5$

4. "Known Geothermal Resource Areas" in Nevada ........... 10

\section{TABLES}

Table 1. Exploratory geothermal drilling in Nevada through $1973 \ldots \ldots \ldots 667$

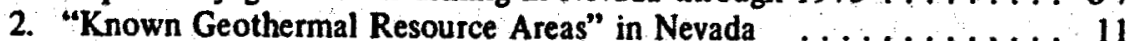




\section{if \\ GEOTHERMAL EXPLORATION AND DEVELOPMENT IN NEVADA THROUGH 1973}

\section{Larry J. Garside}

\section{General}

Geothermal energy is simply the natural heat of the earth. The earth can be thought of as a great furnace with the amount of contained heat so vast that it is impossible to comprehend. It has been estimated, for example, that heat equivalent to the combustion of 300 million barrels of oil is released if 1 cubic mile of hot, near-surface rock is cooled from $625^{\circ} \mathrm{F}$ to $350^{\circ} \mathrm{F}$. The problem is in extracting and utilizing this energy.

The source of the earth's heat, which increases with increasing depth beneath the surface, is believed to be due to the decay of radioactive elements as well as to frictional (tidal) forces. Because heat continues to be produced, one should think of the earth as a heat generator, not simply as a reservoir.

At present it is probably not economically feasible to drill a deep well in any arbitrary area and obtain useful quantities of heat. Therefore, for the near term, geothermal energy utilization will be concentrated in those areas of the world where "hot spots" are known to occur, for example, the "Ring of Fire"-the belt of volcanoes and earthquake activity many thousands of miles in length that circles the Pacific Ocean. Nevada is located within this tectonically active belt. Hot springs or other areas where temperatures increase more rapidly than normal with depth, may indicate near surface sources of heat, such as magma chambers, or hot; recently solidified rock. If water flows through such heated zones, it will in turn become heated. Therefore it is in these areas, where water can act as a transfer agent for the heat, that exploration for geothermal energy will be concentrated.

Although geothermal energy can be used directly for space heating, exploration in the near future will concentrate on finding naturally-heated reservoirs that can produce steam or hot water for use in electric-power generation. The so-called dry steam fields, like The Geysers in northern California, are probably rare in nature. When wells are drilled to tap a geothermal reservoir, the product may be dry steam unaccompanied by liquid water, or it may be extremely hot water at elevated pressure. Hot water fields are much more common, but more complicated equipment will be required to best utilize their energy. Minerals are much more soluble in hot water than in cold, therefore these fields often yield water with considerable amounts of dissolved minerals. The amount of dissolved mineral matter also varies from one geothermal area to another. Dissolved minerals can clog and corrode pipe and generating facilities, and equipment to handle these problems is still mainly in the experimental stages. (For example, down-the-hole heat exchange systems could prevent the mineral-laden water from coming in contact with generating equipment).

At the present time, seven countries-Italy, New Zealand, Japan, Mexico, Iceland, the USSR, and the USA-derive electricity from geothermal steam (Grose, 1972). Hydroelectric power is the only power source that has been found to be cheaper than geothermal power, and then only in certain cases. At The Geysers, Calif., the only U.S. installation, geothermal electric power has proven to be cheaper than power from other fuel sources, regardless of plant size (Koenig, 1973). The cost of generation at The Geysers is in fact, about two-thirds of that which could be obtained from a coal-fired plant. The Geysers presently produce enough electricity to supply about 300,000 persons (about half of San Francisco's needs).

\section{Nevada Resources}

Nevada's geothermal resources have great potential, but only a few of the many areas with potential have been examined in any detail. Some of these areas have been studied by private groups, but the information is not readily available. To fill the information gap, the Nevada Bureau of Mines and Geology is compiling all available data on the geothermal resources of the State, and, in addition, is doing some fieldwork on neglected areas. This information is on file at the Bureau office in Reno, and is available for public inspection. The data will later be assembled into a published report (Garside and Schilling, in preparation). A map showing 186 hot spring locations and names has already been published (Horton, 1964a). The authors and the Bureau would appreciate any additional information to help fill the many gaps in our records.

\section{Use}

Hot springs and wells are scattered over the entire State (fig. 1), and there are at least 300 thermal springs known in Nevada. The use of hot springs in Nevada dates back to prehistoric time, when Indians used them for bathing, scalding ducks and geese, and as an aid in removing the pitch from pinyon-pine cones and seeds. Early explorers and the wagon trains of the 49'ers used the hot springs for drinking, bathing, and watering stock. Because of the State's arid climate, water, even if mineralized and hot, has always been an important resource. The waters of almost all the springs 


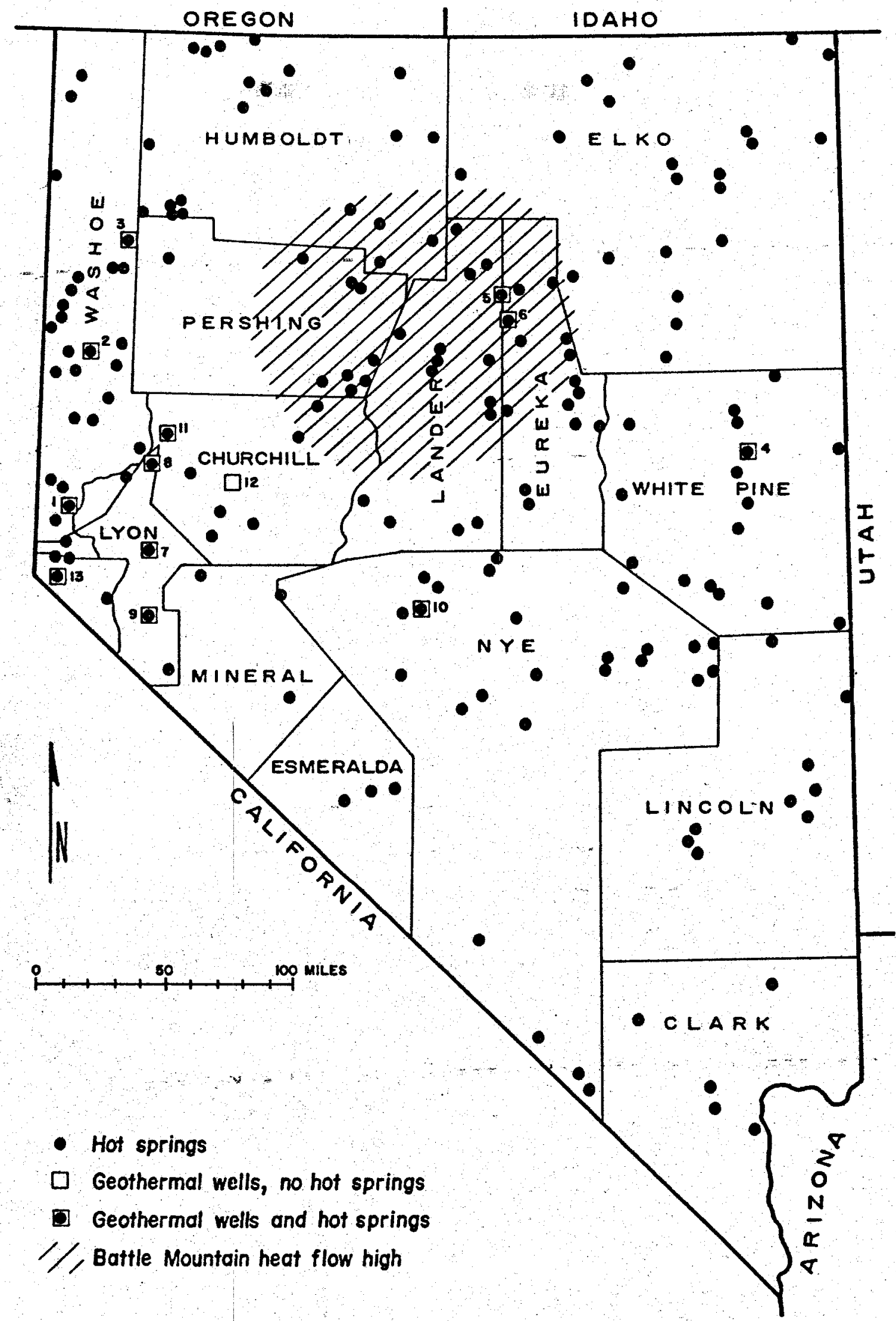

FIGURE 1. Hot springs and geothermal wells in Nevada. Numbers correspond to those of table 1 , which gives drilling details. 
in the State, whether hot or not, have been appropriated for some beneficial use. The mines of the Comstock Lode at Virginia City were famous for the great quantities of hot water encountered. At Tonopah 3 million gallons of hot water were pumped every day from the workings; the flow from the Tonopah mines was used to operate greenhouses. In the 1800's and early 1900 's resorts grew up around many of the hot springs. Many of these spas are now gone, but some are still found; for example, those at Steamboat and Lawton's Hot Springs near Reno. Today many hot spring areas are used for swimming and other recreational activities. Swimming pools using the naturally heated water from hot springs are common in the less populated areas of the State. The hot water, either from springs or shallow wells, is often suitable for use in pools with no treatment, although mixing of water of various temperatures may be necessary. Natural pools and ponds of hot water at hot springs can be near boiling and are extremely dangerous. When investigating hot spring areas persons should exercise considerable caution. (Hot mud often occurs under a seemingly solid surface. This surface may break under a person's weight).

Steamboat Hot Springs, 8 miles south of Reno, have been used for several commercial purposes, including bath resorts, processing asphalt emulsions, and in the melting and casting of plastic explosives. The hot water from Moana Hot Springs in Reno has been used in the past to melt winter ice and snow from streets. In the Stillwater area near Fallon in west-central Nevada, steam and hot water were encountered while drilling water wells in an area where there were no hot springs, and have been used to heat dwellings in this farming area. A number of homes in the southwestern part of Reno (along the Steamboat-MoanaLawton's thermal anomaly) are heated by simple heatexchange systems that utilize the heat from hot water encountered in wells. This source of home heating has considerable potential.

The heating of greenhouses with naturally heated water is a use of geothermal resources which also has considerable potential. At Wabuska, near Yerington, water at temperatures of over $200^{\circ} \mathrm{F}$ is being used to heat greenhouses for growing vegetables, especially tomatoes. Geothermally heated greenhouses are also in use at Wally's Hot Springs near Minden, and at Wendel Hot Springs near Honey Lake, Calif. (near the California-Nevada boundary).

Although no electricity is generated in Nevada from geothermal steam, the utilization of geothermal energy for electric-power generation is probably its highest potential dollar-value use. Although technological problems remain, the State is blessed with several areas that may soon be the sites of geothermal generating facilities, possibly utilizing heat-exchange systems.

Geothermal energy is of special importance to Nevada. Electric power needs in the State are expanding at a rapid rate because of the rapidly expanding population and increased per capita consumption, as well as the extension of transmission lines to many remote areas. A map by Lockard (1970) shows the location of Nevada's transmission and transportation facilities, including electrical powertransmission lines. Power consumption in Nevada is expected to double by 1980 , rising to about 12 million megawatt-hours per year. Generating capacity in Nevada may well rise to an even higher level, as generating facilities are constructed in Nevada to supply the needs of population centers in California as well as the local users. Nevada's entire population of over half a million could be supplied by a single 1000 -megawatt nuclear plant, or by a geothermal field the size of The Geysers in northern California (when this field is fully developed). Obviously the demand for electrical energy from outside the State will greatly influ: ence both the development of electric generation facilities and the exploration for new energy sources, including geothermal power.

\section{Geology}

The Basin and Range physiographic province, in which Nevada is located, is an area of high heat flow, believed to result from near melting conditions in the lower crust and upper mantle. The west-central and north-central areas of Nevada have higher hot spring temperatures (Koenig, 1970) and are regions of greater than normal heat flow. An area of conspicuously higher heat flow, called the "Battle Mountain high," is located in north-central Nevada (fig. 1). The boundaries of this region, and possibly others as yet undetected, need to be delineated by more systematic heat-flow surveys. This would provide useful guidance in the search for economically exploitable geothermal fields (Sass and others, 1971). The Battle Mountain high has an indicated average heat flow of about three heat flow units (two heat flow units is about average for Nevada), but the thermal gradients, which range from $30^{\circ}$ to $60^{\circ} \mathrm{C} / \mathrm{km}$ (about $2.6-4.3^{\circ} \mathrm{F} / 100 \mathrm{ft}$.) are not as high as might be expected, because of relatively high thermal conductivities of the rocks in this area (White, 1973). The Battle Mountain high may be the result of fairly recent intrusion of magma into the earth's crust. The Quaternary yolcanism within the region suggests that this view is reasonable (Sass and others, 1971).

Nevada has a considerable range in mean annual temperature due both to its variations in elevation and its extent over approximately 7 degrees of latitude. The mean monthly temperature usually varies $15^{\circ}$ to $20^{\circ} \mathrm{F}$ from northern to southern Nevada. For this reason, comparisons of hot spring temperatures with a statewide mean annual air temperatures are usually not worthwhile.

In many areas of the world, hot springs and other hightemperature phenomena such as fumeroles are associated with geologically young igneous rocks, commonly less than 5 million years old. Young volcanic rocks or active volcanoes at the earth's surface of ten indicate that hotter bodics of rock, or fluid magma, are present below, in the upper part of the earth's crust.

Nevada lies in the center of a large province of Cenozuic volcanic rocks. Although many of these rocks are 10 to 30 million years old, younger volcanic rocks are found in many areas. In Nevada, young volcanic rocks are found in the Mono Lake-Aurora area of southwestern Mineral County and adjacent California; in southwestern Eurcka County, north of Silver Peak (Esmeralda County), in the Carson and Virginia Ranges near Reno, at Lunar Crater in northeastern Nye County, at the north end of the Fisli Creek Mountains 


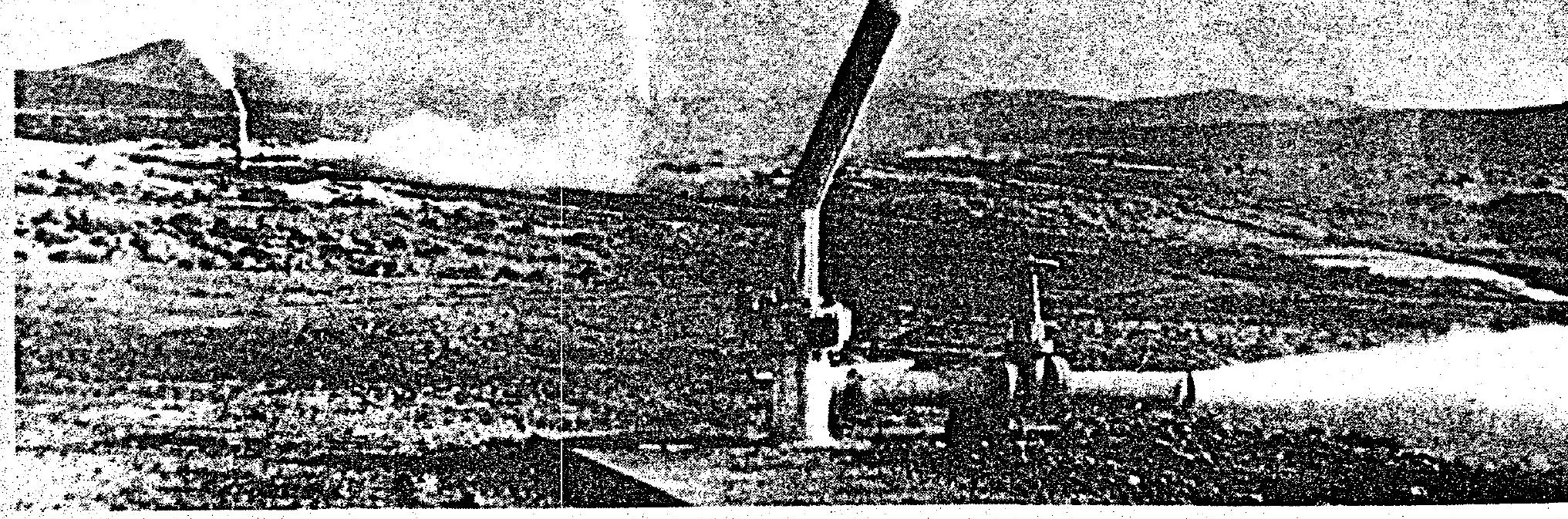

Steam wells at the Beowawe geothermal area, shortly after their. completion in 1959. (photo courtesy of Southern Pacific Transportation $\mathrm{Ca}$ )

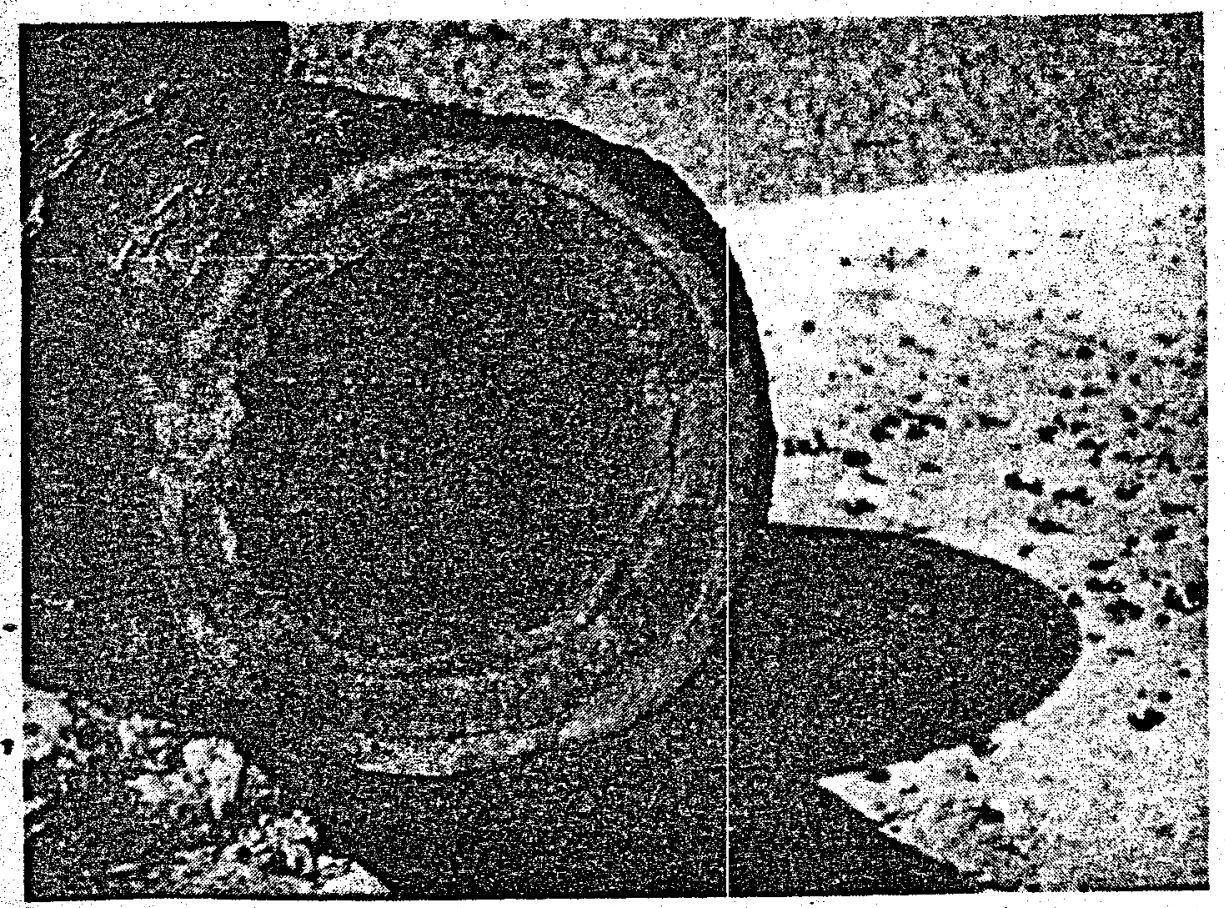

Travertine $\left(\mathrm{CaCO}_{3}\right)$ deposited in the pipe from a geothermal well at Brady's Hot Springs, Churchill County. 
in northern Lander County, in Reveille Valley and the Amargosa Desert in Nye County, on Railroad Point in northwestern Humboldt County, and in the WinnemuccaBattle Mountain area of north-central Nevada, as well as in a number of other areas. K-Ar (potassium-argon) dating has defined the age relations of many volcanic centers in Nevada, and will continue to be useful in the future. (Age dates on Nevada rocks are listed in Nevada Bureau of Mines and Geology Report 10, and additional data have been and will continue to be reported in various articles of the journal Isochron/West).

Many of Nevada's numerous hot springs occur along major faults which bound the State's mountain ranges. The basin-and-range pattern of linear, north-south-trending mountain and valley blocks is a result of these faults. The ground water in the valleys often circulates to considerable depths along some of these fractures, and is heated by the hotter rocks found at these depths. If one knows the approximate geothermal gradient, the depth of circulation of ground water can often be estimated from water temperatures of springs (assuming little cooling has taken place as the water ascends to the surface). The ground water

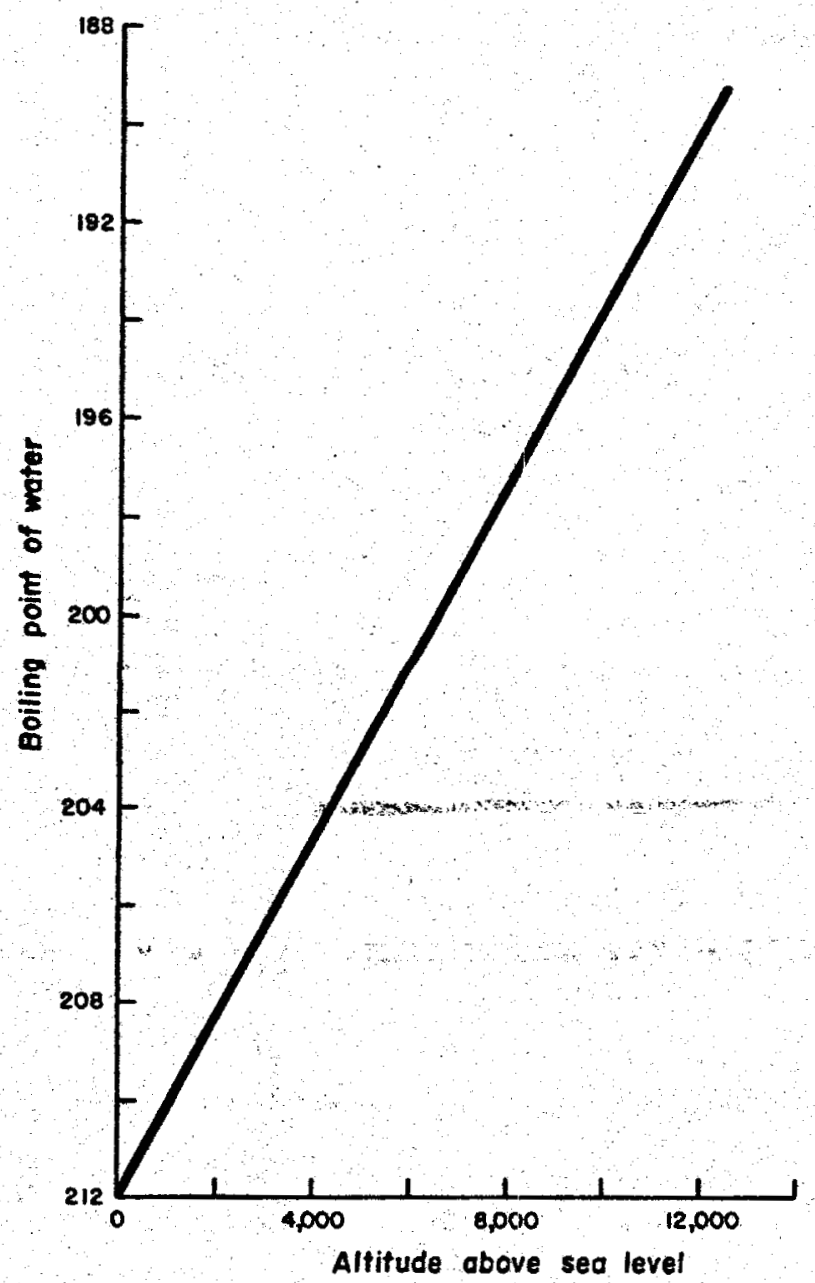

FIGURE 2. Variation of the boiling point of water with altitude above sea level Data from Waring (1965). under many of Nevada's valleys is measured in the millions of acre feet per basin.

Hot-spring temperatures in the State range up to boiling, although surface water measurements on boiling springs will commonly be somewhat below the boiling point for any given elevation because surface evaporation and other cooling phenomena may substantially reduce water temperatures. The best measurements are usually made directly in the orfice of the spring, below the water surface where the flow is greatest. Below altitudes of 5,000 meters (about 16,000 feet), the boiling point of water decreases $1^{\circ} \mathrm{F}$ for each 550 feet $\left(1^{\circ} \mathrm{C}\right.$ for each 303 meters) increase in elevation above sea level. Figure 3 is a graph showing altitude plotted against the boiling point; from this graph it can be seen that a spring at an elevation of 6,500 feet will be boiling at water temperatures nearly $12^{\circ} \mathrm{F}$ below the sealevel boiling point. Conversely, the boiling point rapidly increases with depth below the earth's surface (see fig. 4). Gases in solution lower the boiling point while mineral substances in solution raise the boiling point (however, the effect of elevation of depth is much greater than any change. due to dissolved materials).

The major portion of Nevada's hot springs are found in the northern half of the State. Among the many geothermal

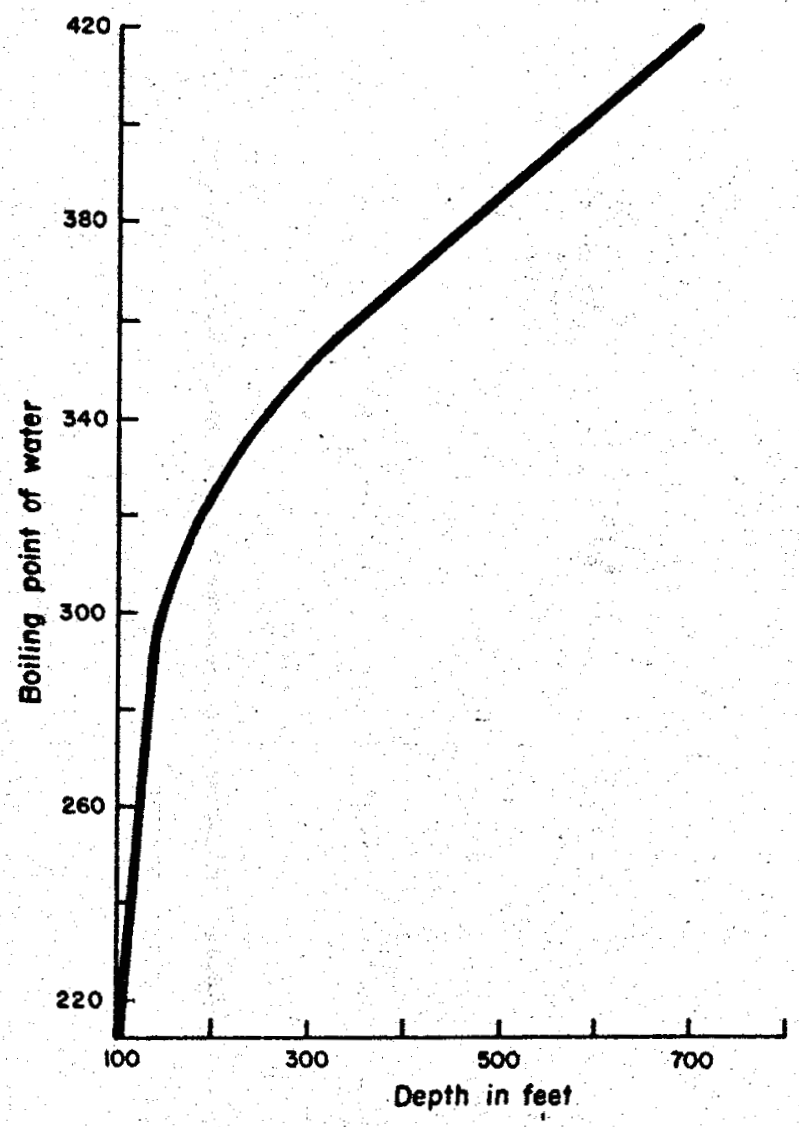

FIGURE 3. Variation of the boiling point of water with depth below a water surface at sea level. Data from Waring (1965). 
TAALE 1

Exploratory goothermal drilling in Nevada through $1973^{\circ}$

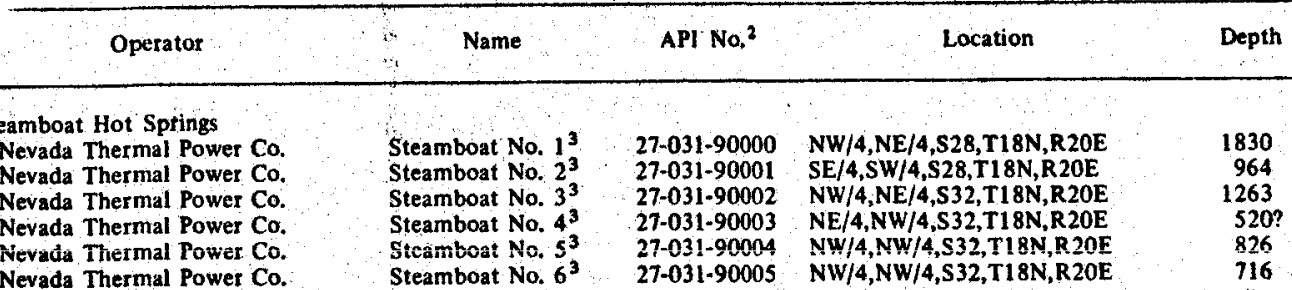

2. The Needles (Pyramid Lake) Western Geothermat Inc. Western Geothermal Inc.

3. Wards Hot Springs (Fly Ranch) Western Geothermal Inc. Western Geothermal Inc

\begin{tabular}{|c|c|c|}
\hline $\begin{array}{l}\text { Maximum Spring } \\
\text { Temp }\left(\mathrm{O}^{\mathrm{F}}\right)\end{array}$ & $\begin{array}{l}\text { Maximum Well } \\
\text { Temp. ( }\end{array}$ & $\begin{array}{c}\text { Completion } \\
\text { Date }\end{array}$ \\
\hline
\end{tabular}

369

.

$\begin{array}{ll}27.031-90006 & \mathrm{NW} / 4, \mathrm{SW} / 4, \mathrm{SW} / 4, \mathrm{~S} 6, \mathrm{~T} 26 \mathrm{~N}, \mathrm{R} 21 \mathrm{E} \\ 27.031-90007 & \mathrm{C} W / 2, \mathrm{NE} / 4, \mathrm{~S} 12, \mathrm{~T} 26 \mathrm{~N}, \mathrm{R} 21 \mathrm{E}\end{array}$ Needles No. 2(?)

$27-031-90007$

NW/4,SW/4, SW/4, S6,T26NE

5888
$4000 ?$

Fly Ranch No. $1(?)^{3}$

27-031-90009.SW/4,S2,T34N,R23E

27-031-90010 S35(?), T34N,R23E

4. Monte Neva Hot Spring Magma Power Co.

5. Beowawe Geysers' Magma Power Co. agma Power Co.

Vulcan Thermal Power Co Vulcan Thermal Power Co. Vulcan Thermal Power Co. Vulcan Thermal Power Co. Vulcan Thermal Power Co. Uulcan Thermal Power Co. Sierra Pacifle Power Co.(?) Sierra Pacific Power Co.(? $)^{3}$ Sierra Pacific Power Co.(? $)^{3}$ Chervon-American Thermal Res No. $1(?)^{3}$

Monte Neva No. $1(?)^{3} \quad 27-033-90000$ S24(?),T21N,R63E

$1000+$

800

402

208

240

Beowawe No. 1

Beowawe No. 2

Vulcan No. 1

Vulcan No. 2
Vulcan No. 3

Vulcan No. 4

Vulcan No. 5

Vulcan No. 6

Sienta No 1

Sierra No.

Sierra No

Sierra No 4

Ginn No. 1-13
27-011-90000 NE/4,SE/4,NW/4,S17,T32N,R48E $\mathrm{SE} / 4, \mathrm{SW} / 4, \mathrm{NW} / 4, \mathrm{~S} 17, \mathrm{~T} 32 \mathrm{~N}, \mathrm{R} 48 \mathrm{E}$ 27-011-9002 NW/4, R8E 795 or 715 S7? 77-011-90007 NW/4 SW/4,NE/4 S17 T32N R 48E $27.011-90008$ $27.011-90009$
$2717 ?, T 32 N, R 48 E$
$27.011-90010$ 27-011-90011 NW/4,NE/4,NW/4,S17, T32N,R 48E 27-015-90000 C,SE/4,SE/4,S1 3, T3IN,R47E

27-011-90012 S1,2, or 11,T29N,R48E

767
237
478
927
397
2052
1005
-

203

?

1959
$1960 ?$
1960
1961
1961

6. Hot Springs Point (Crescent Valley) Magma Power Co.

\section{Hot Springs Point
No. $1(?)^{3}$}

Hot water present with $5-10 \%$ steam nashover. Elest core holes drilled by the U. S. Geological Survey (1950), for a total Also several wells for hot water baths, ete. Numerous homes are heated from warm water wells in the Renc area. For more information see Whit

(1968)

Large flow of hot water.

Largest hot springs in northwestern Nevada.

Melvin (Goodrich) Hot Springs

Hot water with 5-10\% steam flashover. Problems of scaling and cold water innow. 
TABLE I (Continued)

Bxplontory geothermal drilling in Nevada through $1973^{2}$

\begin{tabular}{|c|c|c|c|c|c|c|c|c|}
\hline Operator & Name & $\mathrm{API} \mathrm{Na}{ }^{2}$ & Location & Depth & $\begin{array}{l}\text { Maximum Spring } \\
\text { Temp. (PF) }\end{array}$ & $\begin{array}{l}\text { Maximum Well } \\
\left.\text { Temp. ( }{ }^{\circ} \mathrm{F}\right)\end{array}$ & $\begin{array}{c}\text { Completion } \\
\text { Date }\end{array}$ & Remarks \\
\hline $\begin{array}{l}\text { 7. Wabuska Hot Springs } \\
\text { Magma Power Co. } \\
\text { Magma Power Co. } \\
\text { Magma Power Co. }\end{array}$ & $\begin{array}{l}\text { Wabuske No. } 1 \\
\text { Wabuske Na. } 2 \\
\text { Wabuske No. } 3\end{array}$ & $\begin{array}{l}27-01990000 \\
27-01990001 \\
27-01990002\end{array}$ & $\begin{array}{l}\text { S16,T1SN,R2SE } \\
\text { SE } /, \text { NE } / 4, \text { SW/4,S16,T1SN,R2SE } \\
\text { NE/A,SE/4,SE/4,S16,T1SN,R2SE }\end{array}$ & $\begin{array}{c}488 \\
532 ? \\
2223\end{array}$ & 162 & 222 & $\begin{array}{l}1959 \\
1959 \\
1959\end{array}$ & $\begin{array}{l}\text { Hot water used for green- } \\
\text { house heating }\end{array}$ \\
\hline $\begin{array}{l}\text { 8. Ferniey (Hazen) } \\
\text { Magma Power Co. } \\
\text { Magma Power Co. } \\
\text { Magma Power Co. }\end{array}$ & $\begin{array}{l}\text { Hazen No. } 1(?)^{3} \\
\text { Hazen No. } 2(?)^{3} \\
\text { Hezen No. } 3(?)^{3}\end{array}$ & $\begin{array}{l}27-019-90003 \\
27-019-90004 \\
27-019-90005\end{array}$ & $\begin{array}{l}\text { SW/4,S18?,T20N,R26E } \\
\text { S18?,T20N,R26E } \\
\text { S18?,T20N,R26E }\end{array}$ & $\begin{array}{l}750 \\
\text { v300? } \\
\sim 300 ?\end{array}$ & $?$ & 270 & $\begin{array}{l}1962 \\
1962 \\
1962\end{array}$ & Patua Hot Springs. \\
\hline $\begin{array}{l}\text { 9. Hind's Hot Springs } \\
\text { U. S. Steel Corp. } \\
\text { U. S. Steel Corp. } \\
\text { U, S. Steel Corp. }\end{array}$ & $\begin{array}{l}\text { Hind's No. } 1(?)^{3} \\
\text { Hind's No. } 2(?)^{3} \\
\text { Hind's No. } 3(?)^{3}\end{array}$ & $\begin{array}{l}27-019-90006 \\
27-019-90007 \\
27-019-90008\end{array}$ & $\begin{array}{l}\text { SW/4,SE/4,S16,T12N,R23E } \\
\text { SW/4,SE/4,S16,T12N,R23E } \\
\text { SW/4,SE/4,S16,T12N,R23E }\end{array}$ & $?$ & 144 & $?$ & $\begin{array}{l}1962 ? \\
1962 ? \\
1962 ?\end{array}$ & $\begin{array}{l}\text { Hot water in wells cooles } \\
\text { than springs at surface. }\end{array}$ \\
\hline $\begin{array}{l}\text { 10. Darrough Hot Springi } \\
\text { Magma Power Co. }\end{array}$ & Dartough No, $1(?)^{3}$ & $27-023-90000$ & S17?,TIIN,R43E & 812 & $207 ?$ & 265 & 1962 & $\begin{array}{l}\text { Very large flow of hot } \\
\text { water, little steam. }\end{array}$ \\
\hline $\begin{array}{l}\text { 11. Brady's Hot Springs } \\
\text { Magma Power Co. } \\
\text { Magma Power Co, } \\
\text { Magma Power Co. } \\
\text { Magma Power Co. } \\
\text { Magma Power Co. } \\
\text { Magma Power Co. } \\
\text { Magma Power Co. } \\
\text { Earth Energy Inc. } \\
\text { Earth Energy Inc. }\end{array}$ & $\begin{array}{l}\text { Brady No. } 1 \\
\text { Brady No. } 2 \\
\text { Brady No. } 3 \\
\text { Brady No. } 4 \\
\text { Brady No. } 5 \\
\text { Brady No. } 6 \\
\text { Brady No. } 7 \\
\text { R. Brady EE No. } 1 \\
\text { Brady Pros No. } 1\end{array}$ & $\begin{array}{l}27-001-90000 \\
27-001-90001 \\
27-001-90002 \\
27-001-90003 \\
27-001-90004 \\
27-001-90005 \\
27-001-90006 \\
27-001-90007 \\
27-001-90008\end{array}$ & $\begin{array}{l}\mathrm{NE} / 4, \mathrm{NE} / 4, \mathrm{SW} / 4, \mathrm{~S} 12, \mathrm{~T} 22 \mathrm{~N}, \mathrm{R} 26 \mathrm{E} \\
\mathrm{NE} / 4, \mathrm{NE} / 4, \mathrm{SW} / 4, \mathrm{~S} 12 \mathrm{~T} 22 \mathrm{~N}, \mathrm{R} 26 \mathrm{E} \\
\mathrm{SE} / 4, \mathrm{SE} / 4, \mathrm{NW} / 4, \mathrm{~S} 12, \mathrm{~T} 22 \mathrm{~N}, \mathrm{R} 26 \mathrm{E} \\
\mathrm{SE} / 4, \mathrm{SE} / 4, \mathrm{NW} / 4, \mathrm{S12}, \mathrm{T} 22 \mathrm{~N}, \mathrm{R} 26 \mathrm{E} \\
\mathrm{NW} / 4, \mathrm{SW} / 4, \mathrm{NE} / 4, \mathrm{~S} 12, \mathrm{~T} 22 \mathrm{~N}, \mathrm{R} 26 \mathrm{E} \\
\mathrm{NW} / 4, \mathrm{SW} / 4, \mathrm{NE} / 4, \mathrm{~S} 12, \mathrm{~T} 22 \mathrm{~N}, \mathrm{R} 26 \mathrm{E} \\
\mathrm{NW} / 4, \mathrm{SW} / 4, \mathrm{NE} / 4, \mathrm{S12} \mathrm{T} 22 \mathrm{R}, \mathrm{R} 26 \mathrm{E} \\
\text { S12?,T22N,R26E } \\
\text { S12?,T22N,R26E }\end{array}$ & $\begin{array}{l}700 ? \\
241 \\
610 \\
723 \\
593 \\
770 \\
250 \\
5062 ? \\
1758 ?\end{array}$ & 194 & 418 & $\begin{array}{l}1959 ? \\
1959 ? \\
1961 ? \\
1961 ? \\
1961 ? \\
? ? \\
? \\
1964 \\
1965 ?\end{array}$ & $\begin{array}{l}\text { Hot water with } 5 \% \text { steam } \\
\text { flashover. Problem of } \\
\text { scaling. }\end{array}$ \\
\hline $\begin{array}{l}\text { 12. Stillwater } \\
\text { O'Neill Geothermal, Inc. }\end{array}$ & $\begin{array}{l}\text { Joseph I. O'Neil, Jt: } \\
\text { Reynolds No. } 1\end{array}$ & 27-001-90009 & $\mathrm{NE} / 4, \mathrm{SW} / 4, \mathrm{SW} / 4, \mathrm{~S} 6, \mathrm{~T} 19 \mathrm{~N}, \mathrm{R3} 1 \mathrm{E}$ & $24200 ?$ & - & 240 & 1964 & $\begin{array}{l}\text { Some water wells drilled } \\
\text { in this area encountered } \\
\text { hot water and steam } \\
\text { which have been used for } \\
\text { space heating. No springs } \\
\text { or other surface features. }\end{array}$ \\
\hline $\begin{array}{l}\text { 13. Wally's Hot Springs } \\
\text { U. S. Steel Corp. } \\
\text { U. S. Steel Corp. }\end{array}$ & $\begin{array}{l}\text { Wally's No. } 1 \\
\text { Wally's No. } 1\end{array}$ & $\begin{array}{l}27-005-90000 \\
27-005-90001\end{array}$ & $\begin{array}{l}\text { SE/4,NW/4,NW/4,S22,T13N,R19E } \\
\text { SW/4,SW/4,NW/4,S22,T13N,R19E }\end{array}$ & $\begin{array}{r}1268 \\
499\end{array}$ & 160 & 181 & $\begin{array}{l}1962 \\
1962\end{array}$ & $\begin{array}{l}\text { Twenty-six shallow holes } \\
\text { were atso drilled to meas } \\
\text { ure the temperature } \\
\text { gradient. }\end{array}$ \\
\hline
\end{tabular}

I Listing does not include thermal water wells or wolls drilied to exploit thermal waters for spas, swimming pools, space heating, etc.

${ }^{2}$ The American Petroleum Institute. Unique well number system has been applied to geothermal wells as well as oil and gas wells, and

is recommendod for the unique identification of wells by all azencies of industry and government.

SName issigned by Nevach Bureau of Mines and Geology; original name unknown 
areas shown on figure 1 , the hottest subsurface temperatures were encountered at Beowawe, Brady's, and Steamboat Hot Springs (see table 1).

\section{Exploration}

Only in the last decade have serious attempts been made to exploit Nevada's geothermal resources as a source of power. Nevada ranks second only to California in total geothermal exploration activity to date. Exploratory drilling in 13 geothermal areas took place in the period between 1959 and 1965. Although many of these wells were less than 1,000 feet in depth, temperatures of $300^{\circ}$ to $400^{\circ} \mathrm{F}$ were encountered at several areas. At least four wells were drilled to depths of more than 3,500 feet, and the deepest well (Western Geothermal Inc., Needles No. 1) is 5,888 feet deep (table 1).

The cessation of exploratory drilling in the mid-1960's was due in large part to the problems of leasing on Federal land. Also, Nevada's geothermal resources appear to be mainly in hot water systems rather than dry steam, and interest in this type of field was low in the early part of the 1960's. Today, with changes in energy supply and investment attitudes, exploration is once again being carried on in Nevada for geothermal power. Drilling activity in 1973 has been limited to holes for temperature gradient measurements. However, Standard Oil Co. of California and American Thermal Resources began a well in January of 1974 near the Beowawe geothermal area, the first well in Nevada since the mid-1960's. Several other wells are also planned in western Nevada. When leases are finally issued for Federal lands, test wells are expected in several areas.

Because most of Nevada is Federal land, exploration companies have been reluctant to drill in areas where they cannot control a reasonable surrounding acreage. The leasing of privately owned land has increased over the past year, with the Stillwater-Soda Lake area probably having the most activity. Several major oil companies have been exploring in the area, and geothermal leases have been signed by a number of private landowners. Exploration has also been undertaken in the Brady-Hazen area, on the Walker River Indian Reservation, at Steamboat Springs south of Reno, near Golconda, and in the Gerlach-Fly Ranch area of northwestern Nevada, to name only a few areas.

The U. S. Geological Survey is currently conducting geologic, geochemical, and geophysical studies of several geothermal areas in Nevada (oral cornmunication, 1973, R. K. Hose). Heat-flow measurements by the Survey also are continuing, especially in northwestern Nevada (oral communication, 1973, J. H. Sass). A recent U. S. Geological Survey report (Olmsted and others, 1973) lists sources of dafa for several geothermal areas in northern and central Nevada.

The Atomic Energy Commission has begun geologic and geophysical investigations in northern Nevada to find an area suitable for the generation of electricity from geothermal water. The project is being carried out by the Lawrence Berkeley Laboratory, University of California, Berkeley. When and if such a site were selected, a 10,000kilowatt pilot generating plant would be considered. For this purpose the A.E.C. has asked the U. S. Bureau of Land
Management to withdraw about 88,000 acres in northem Nevada from geothermal leasing for a period of not more than 2 years.

A recent National Science Foundation grant to study the use of electrical methods for the delineation of geothermal reservoirs will involve resistivity, self-potential, induced polarization, and electromagnetic measurements in Nevada's geothermal areas. H. F. Morrison, University of California, Berkeley, is the principal investigator.

Research projects on geothermal energy funded by the National Science Foundation's RANN (Research Applied to National Needs) program have been proposed for several areas of the United States, including Nevada. If the recommendations of the Geothermal Resources Research Conference are implemented, $\$ 684.7$ million would be invested over 10 years to probe the engineering and production unknowns and to learn to understand and utilize geothermal energy (Hickel, 1973).

Exploration activity in Nevada by private companies in the past year has consisted of geologic studies, heat flow and temperature gradient measurements, water analyses, and various geophysical investigations (gravity, magnetics, microseismic, "ground noise," electrical resistivity, etc.). Grose (1971) presents a review of the various exploration methods used in the search for geothermal energy. Many of these methods have been used in Nevada.

There are numerous sources of general background information on the geology of Nevada. Most of the geologic and geophysical reports and maps have been published either by the Nevada Bureau of Mines and Geology or the U. S. Geological Survey. For help in determining what is available, (including unpublished information) contact the Nevada Bureau of Mines and Geology (on the University of Nevada, Reno campus: (702) 784-6691).

\section{Regulation}

An August 1965 opinion by the Deputy Attorney General of Nevada considers geothermal resources as water resources, and has placed the regulatory jurisdiction with the Division of Water Resources, Department of Conservation and Natural Resources. Anyone planning to drill a geothermal well should therefore contact:

Roland G. Westergard, State Engineer

Division of Water Resources

201 South Fall Street

Carson City, NV 89701

(702) 882-7441

The Nevada Division of Environmental Health establishes regulations for all forms of pollution. Although there are no laws specifically dealing with pollution caused by geothermal exploration and development, the general State laws and regulations definitely apply. For more information, contact:

Division of Environmental Health
Department of Health, Welfare, and
Rehabilitation
201 South Fall Street
Carson City, NV 89701
(702) $882-7870$



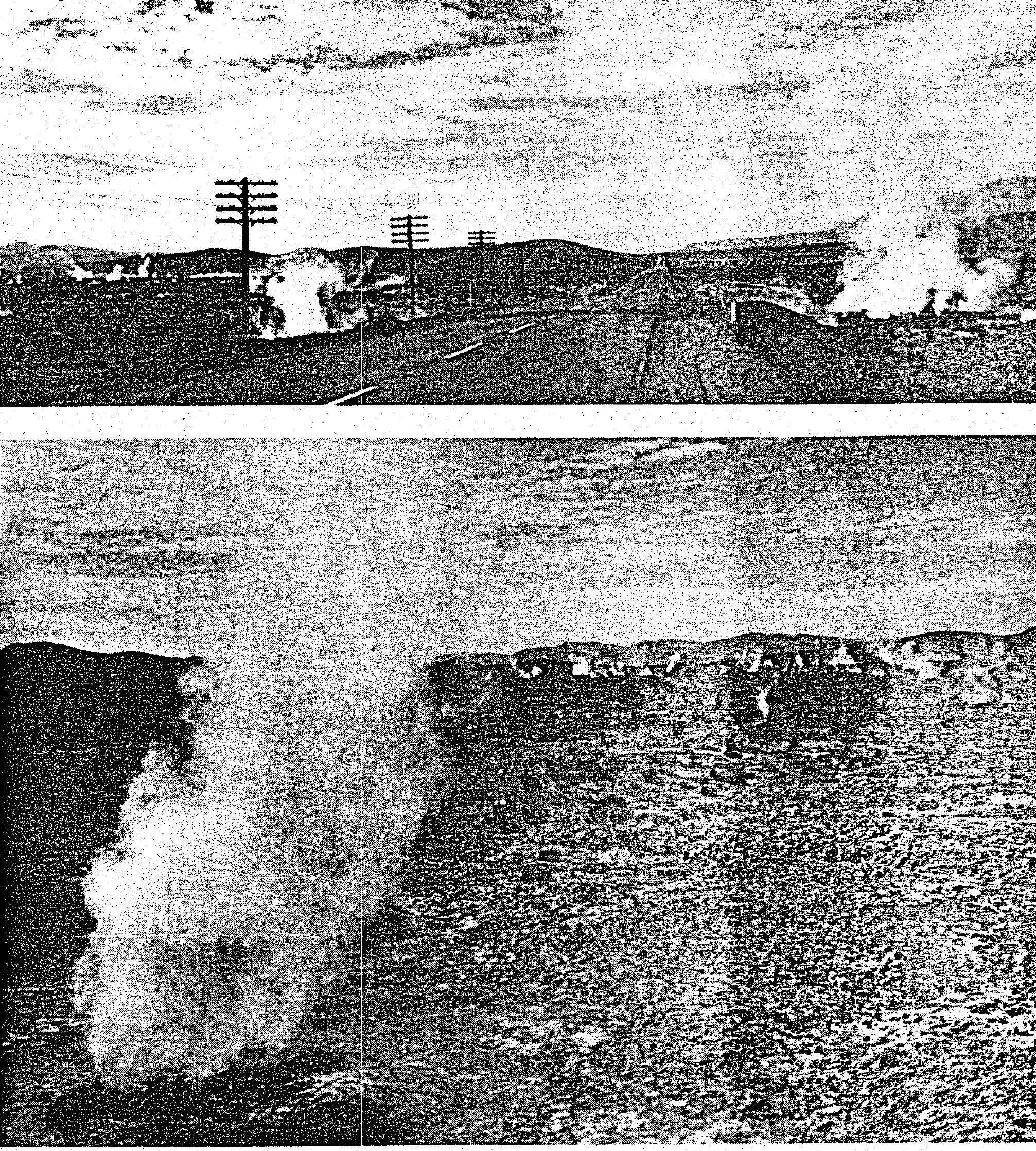

Top: Steam escaping from a fault zone which crossed U.S. Highway $\mathbf{4 0}$ approximately 1 mile north of Brady's Hot Springs, Churchill County. This unusual geothermal activity resulted from a well blow-out following drilling in 1959. (photo courtesy of the Nevada State Highway Department)

Bottom: Close-up of a steam vent which formed after the well blow-out at Brady's Hot Springs Other new vents can be seen in the background. (photo courtesy of the Nevada State Highway Department) 


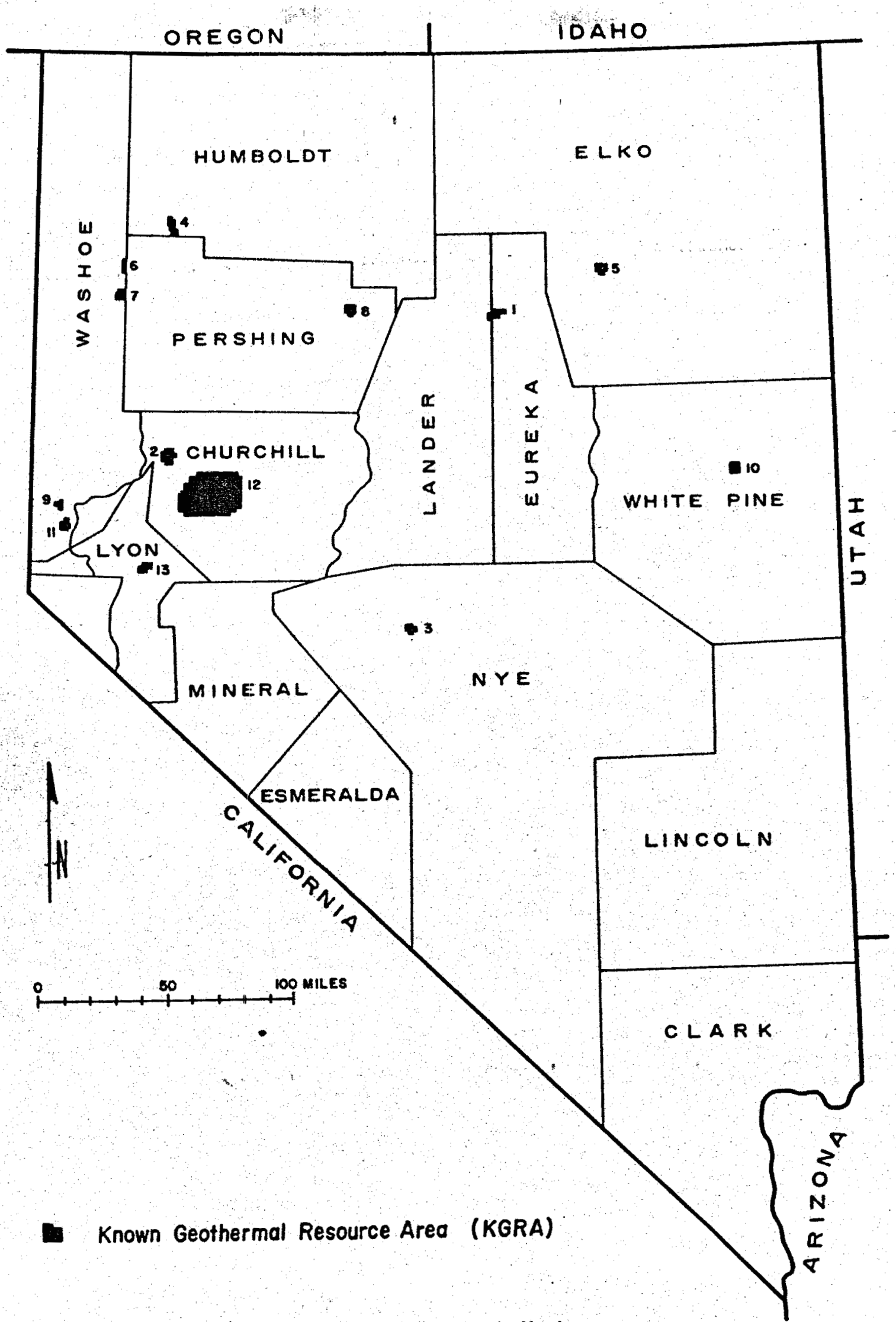

FIGURE 4. "Known Geothermal Resource Areas" in Nevada. Numbers correspond to those of table 2, which gives detailed locations. 


\section{GEOTHERMAL EXPLORATION AND DEVELOPMENT IN NEVADA THROUGH 1973}

Nevada State land consists of less than 1 percent of the 110,540 square miles $(70,745,600$ acres) of total land area. Nearly half of all State-owned land consists of State Parks. Because there is essentially no State land with geothermal potential on which leasing would be allowed, no State geothermal leasing regulations have been issued.

Approximately 86 percent of Nevada's land area is under the jurisdiction of the Federal Government. Much of this land is public domain-public lands under federal management which have not been reserved for special uses such as parks, National Forests, recreation areas, and military installations (Lutsey and Nichols, 1972). Public domain lands in Nevada total approximately 47 million acres (about 66 percent), and are administered by the Bureau of Land Management of the U.S. Department of the Interior. The Secretary of the Interior is authorized by Public Law $91-581$ (The Geothermal Steam Act of 1970) to issue leases for the development and utilization of geothermal steam and associated geothermal resources. Lands administered by the Forest Service, U. S. Department of Agriculture are included in those lands available for geothermal leases.

Proposed leasing and operating regulations to implement the Geothermal Steam Act, and subsequent revisions, were published in the Federal Register on July 23, 1971, November 29, 1972, and July 23,1973, and corrected in the Federal Register of August 8, 1973. Proposed unit plan regulations and revisions were published in the Federal Register on May 3, 1972, November 29, 1972, and July 23, 1973. These regulations provide a framework for leasing, exploration, development, and utilization of geothermal resources on public lands.

The final regulations governing leasing of national resource lands for geothermal energy became effective January 1, 1974. The Bureau of Land Management is accepting applications for leases on all national resource - lands in Nevada except those designated as Known Geothermal Resource Areas (KGRA's). Noncompetitive leases will be issued following an environmental analysis of the area. It is possible that the first leases may be issued by mid-1974. Applications for noncompetitive leases, and further information, may be obtained from the BLM Nevada State Office, 300 Booth St., Room 3008, Reno, NV, 89502.

Twelve areas in Nevada totaling 343,996 acres have been designated as Known Geothermal Resource Areas (see fig. 4). These areas have been so classified by the U.S. Geological Survey, and include areas for which the prospects for extraction of geothermal steam or associated geothermal resources were considered good enough to warrant expenditures of money for that purpose (Godwin and others, 1971). The public portions of these lands will become available for lease from the Federal Government for geothermal steam and associated geothermal resources only by competitive bidding under regulations formulated by the Secretary of the Interior. The Bureau of Land Management is responsible for issuing geothermal leases for public lands. Nevada KGRA's have varying amounts of privately owned land within their borders, and leases for geothermal exploration on private land must be arranged with the individual owners. The State office of the U. S. Bureau of Land Management in Reno has available for public inspection land plats and
TABLE 2

Known Geothermal Resources Areas (KGRA's) in Nevada* (343,996 acres)

1. Beowawe $(12,712$ acres $)$

Secs. 13,24, T. 31 N., R. 47 E.

Secs. $1-5,7-12,15-20$, T. 31 N., R. 48 E. Sec. 6, T. 31 N., R. 49 E.

2. Brady Hot Springs $(19,020$ acres $)$

Secs. 1-4, 9-16, 21-27, T. 22 N., R. 26 E. Secs. $34-36$, T. 23 N., R. 26 E.

Secs. 6-8, 17-19, 30, T. 22 N., R. 27 E. Sec. 31, T. 23 N., R. 27 E.

3. Darrough Hot Springs $(8,398$ acres)

Secs. $1,12,13$; T. 11 N., R. 42 E.

Secs. 5-9, 16-20, T. 11 N., R. 43 E

4. Double Hot Springs $(10,816$ acres $)$

Secs. $3-5,8-10,15,16,21-23,26,27,34$, T. 36 N., R. 26 E.

Secs. 32, 33, T. 37 N., R. 26 E.

5. Elko Hot Springs $(8,960$ acres)

Secs. $14-17,20-23,26-29,33,34$, T. 34 N., R. $55 \mathrm{E}$.

6. Fly Ranch $(5,125$ acres)

Secs. 1, 2, 11-14, 23, 24, T. 34 N., R. 23 E.

7. Gerlach $(8,972$ acres)

Secs. 3, 4, 8-11, 14-17, 20-23, T. 32 N., R. $23 \mathrm{E}$

8. Leach Hot Springs $(8,926$ acres)

Secs. 1, 2, 12, T. 31 N., R. 38 E.

Secs. $25,26,35,36, T, 32$ N., R. 38 E

Secs. 5-7, T. 31 N., R. $39 \mathrm{E}$.

Secs. 29-32, T. 32 N., R. 39 E.

9. Moana Springs ( 5,120 acres)

Secs. $13,22-26,35,36$, T, 19 N., R. 19 E.

10. Monte Neva $(10,302$ acres)

Secs. 13-15, 22-27, 34-36, T. 21 N., R. 63 E. Secs. 18, 19, 30, 31, T. 21 N., R. 64 E.

11. Steamboat Springs $(8,914$ acres)

Secs 4-6, T. 17 N., R. 20 E.

Secs. $20,21,27-29,31-34$, T. 18 N., R. 20 E.

Sec. 1, T. 17 N., R. 19 E.

Sec. 36, T. 18 N., R. $19 \mathrm{E}$.

12. Stillwater-Soda Lake $(225,211$ acres)

Secs. $1-3,10-15,22-27$, T. 19 N., R. 27 E.

Secs. $24-26,34-36$, T. 20 N., R. 27 E.

Secs. 1-30, 32-36, T. 19 N., R. 28 E.

Secs. $1-5,7-36$, T. 20 N., R. 28 E.

Secs. $13,14,22-28,33-36$, T. 21 N., R. 28 E.

Secs. 1-36, T. 19 N., R. 29 E.

Secs 1-36, T. 20 N., R. 29 E.

Secs. 13-36, T. 2 I N., R. 29 E.

Secs. $1-36$, T. 19 N., R. 30 E.

Secs. 1-36, T. 20 N., R. 30 E.

Secs. 13-36, T. 21 N., R. $30 \mathrm{E}$

Secs. $3-10,15-21,29,30$, T. 19 N., R. 31 E. Secs. $3-10,15-22,27-34$, T. 20 N., R. $31 \mathrm{E}$ Secs. $16-22,27-34$, T. 21 N., R. 31 E.

13. Wabuska $(11,520$ acres $)$

Secs. $9-17,20-24,26-29$, T. 15 N., R. 25 E.

*As determined pursuant to Sec. 21(2), Geothermal Steam Act of 1970 (84 Stat. 1566), and published in the Federal Register v. 36, no. 58, Thurs., Mar. $25,1971$. 
other maps which show land use, ownership, survey markers, and other data.

Nineteen percent of the State, or $13,458,000$ acres, are classified by the U. S. Geological Survey as thaving prospective value". Unless further KGRA's are designated, the non-KGRA public lands will be open to lease by the first qualified person applying, on a noncornpetitive bid basis.

Only about 12 percent of the land area in Nevada, amounting to some 8 million acres, is held in private ownership. The Southern Pacific Co. is the single largest owner of private land, and holds about 1.5 million acres. Over 80 percent of Nevada's private land lies along the route of the Southern Pacific Railroad (and the Humboldt River), forming a 40 -mile wide band across the northern third of the State. Much of the private land in Nevada is available for geothermal exploration and development through lease arrangements with private owners. It is not always clear whether geothermal resources belong to the owners of the surface rights or to the owners of the mineral rights. $A$ recent court decision (The United States v. Union Oil Co., Magma Power Co., and others) indicates that geothermal resources belong with homestead water rights, and not with the mineral rights reserved to the Federal Government. However; this decision may be appealed.

Indian lands, comprising 1.6 percent of the State, may also be available for geothermal exploration through the U. S. Bureau of Indian Affairs or individual tribal councils.

\section{References}

Garside, L. I., and Schilling, J. H., (in preparation), Geothermal resources of Nevada: Nevada Bur. Mines and Geol. Bull.

Godwin, L H., Haigler, L B., Rioux, R. L, White, D. E, Muffler, L. $P . J$, and Weyland, R G., 1971, Classification of public lands valuable for geothermal steam and associated geothermal vesources: U. S. Geol. Survey Circ. 647.

Grose, L. T, 1971, Geothermal energy: geology, exploration, and developments, part 1: Colorado School Mines Mineral Industries Bull., v. 14, no. $6,14 \mathrm{D}$.
1972, Geothermal energy: geology, exploration, and developments, part 2: Colorado School Mines Mineral Industries Bull, v. 15, no. 1,16 p.

Hickel, W. J. (chairman), 1973, Geothermal energy, a national proposal for geothermal resources research: University of Alaska, $95 \mathrm{p}$.

Horton, R. C., 1964a, Hot springs, sinter deposits, and volcanic cinder cones in Nevada: Nevada Bur. Mines Map 25.

$1964 b$, Geothermal power in Nevada: Nevada Bur. Mines Bull. 65, p. $238,267-269$.

Koenig, J. B., 1970, Geothermal exploration in the western United States: United Nations Symposium on the Development and Utilization of Geothermal Resources (Pisa, Italy), Paper 11/19, Geothermics, special issue $2, \mathrm{v} .2$, pt. 1, p. 1-13.

1973, World wide status of geothermal resources, in Kruger, Paul and Otte, Carel (eds.), Geothermal energy-resources, pro duction, stimulation: Stanford Univ. Press, Stanford, Calif.

Lockard, Keith, 1970, Transmission and transportation facilities in Nevada: Nevada Bur. Mines Map 41.

Lutsey, I. A., and Nichols, S. L., 1972, Land status map of Nevada (2nd edition): Nevada Bur. Mines and Geol. Map 40.

Osterling, W. A., 1962, Geothermal power potential of northern Nevada: Southern Pacific Co. report.

Olmsted, F. H., Glancy, P. A., Harrill; J. R., Rush, F. E., and Van Denburgh, A. S., 1973, Sources of data for evaluation of selected geothermal areas in northern and central Nevada: U. S. Geol Survey Water-Resources Inv. $4473,78 \mathrm{p}$.

Sass, J. H., and others, 1971, Heat flow in the western United States: Jour. Geophys. Research, v. 76, no. 26, p. 6376-6413.

Stewart, J. H., (in preparation), Preliminary geologic map of Nevada: U. S. Geol. Survey.

Schilling, J. H., 1968, Nevada's geothermal resources: Nevada Business Review, v. 13, no. 9, p. 3-5.

Waring, G. A., 1965, Thermal springs of the United States and other countries of the world-a summary: U. S. Geol. Survey Prof: Paper 492, $383 \mathrm{p}$.

White, D. E., 1968, Hydrology, activity, and heat flow of the Steambost Springs thermal system, Washoe County, Nevada: U. S. Geol. Survey Prof. Paper 458-C, 109 p.

1973, Characteristics of geothermal resources, in Kruger, Paul and Otte, Carel (eds.), Geothermal energy-resources, production, stimulation: Stanford Univ. Press, Stanford, Calif. 


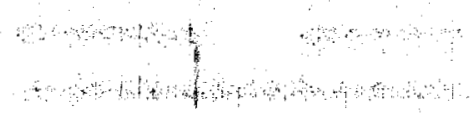

The Mackay School of Mines is the educational, research, and public service center for the geology and mineral industry of Nevada. It is one of the several colleges of the University of Nevada, Reno. The School consists of three divisions: the academic division, composed of the departments of instruction; the Nevada Bureau of Mines and Geology; and the Nevada Mining Analytical Laboratory.

The Nevada Bureau of Mines and Geology and the Nevada Mining Analytical Laboratory, as research and public service agencies, make available information, maps, and reports on the mineral resources and geology of Nevada. Both organizations work on environmental problems, and assist in the development and utilization of the State's mineral resources. The Bureau conducts field studies and other research on geology and mineral deposits. The Laboratory identifies, analyzes, and evaluates minerals, rocks, and ores found in Nevada, and performs research in mineral beneficiation and extractive metallurgy.

For information concerning the geology or mineral resources of Nevada, write to: Director, Nevada Bureau of Mines and Geology, University of Nevada, Reno, Nevada 89507. 